INTERNATIONAL JOURNAL OF RESEARCHES IN BIOSCIENCES, AGRICULTURE AND TECHNOLOGY (C) VISHWASHANTI MULTIPURPOSE SOCIETY (Global Peace Multipurpose Society) R. No. MH-659/13(N) www.vmsindia.org

\title{
WATER ANALYSIS ON THE BASIS OF LENGTH-WEIGHT RELATIONSHIP AND EQUILIBRIUM CONSTANT OF A FISH MASTACEMBELUS PANCALUS (CUV. \& VAL)
}

\author{
R. Dahare \\ Sarvodaya Mahavidyalaya Sindewahi Dist. Chandrapur M.S. 441222 INDIA \\ drrajeshdahare@gmail.com
}

\begin{abstract}
:
Malnutrition is the problem faced by the world and fish is the best source of protein. .Fishery industry is vast all over the world. It performs capture and culture method in fresh and marine water. Study of biology helps in the fish production and also helps in knowing the quality of environment in which fish live. The study of length-weight relationship and equilibrium constant of fish Mastacembelus pancalus was undertaken in this work. It helps in knowing the quality of water body. The equilibrium constant of Mastacembelus pancalus was found to be 3.2528 collected from Wainganga river from Pauni of Bhandara district. The standard equilibrium constant is 3 , when the value is more than three it indicate the river is good enough to provide all conditions to fish Mastacembelus pancalus for its growth.
\end{abstract}

Keyword:- Water analysis, Mastacembelus pancalus, Length-weight relationship, equilibrium constant, Freshwater fish.

\section{Introduction:}

Fishery is the vast industry all over the world. Performing capture and cultivation method in fresh and marine water. Malnutrition is another fascinating problem all around the world which is faced by many countries. Fish is the major source of protein. There is need to enhance the production of fish. In fact the world's fish production is about $90 \%$ in marine and $10 \%$ in inland water. In India this ratio is 60 and $40 \%$ respectively. The study in biology of fish helps in production of fish.

The length-weight relationship and equilibrium constant are important parameter in biology of fish. According Le Cren and others the weight of the fish proportionately increases to the length of fish. If the value of equilibrium constant of fish is constant it is 3 it means it obeys the cube law. But the physical and chemical factor of water body changes the value of equilibrium constant. Which helps in analyzing the quality of water body in relation with growth of fish.

\section{Material and Method:}

The fish Mastacembelus pancalus was collected from the Wainganga river from Pauni of Bhandara district India. Random collection was taken fishes were brings to laboratory in fresh condition and preserved in $10 \%$ formaldehyde. The length of fish were measured from their tip of snout to the last ray of caudal fin in centimeter. The fish was also weighed on single pan balance of $0.1 \mathrm{gm}$. Sensitivity. The fishes were categorized in 17 groups of $0.5 \mathrm{~cm}$. length variation from 4,1 to $12.5 \mathrm{cms}$. The weight of each was taken. The log of mean value of length is called $\mathrm{X}$ and their summation was calculated. The log of mean value of body weight is called $\mathrm{Y}$ and their summation was taken. The equilibrium constant $\mathrm{b}$ is calculated by using formula

$$
\mathrm{b}=\frac{\sum \mathrm{XY}-\mathrm{N}\left(\sum X / N \times \sum Y / N\right)}{\sum \mathrm{X}^{2--} N\left(\sum X / N\right)^{2}}
$$

\section{Observations and Discussion}

The total 150 specimen of Mastacembelus pancalus was collected from the Wainganga river from Pauni of Bhandara district and their data was analyzed in total length and body weight. These were categorized in 17 groups from $4.1 \mathrm{cms}$. to $12.5 \mathrm{cms}$. of $0.5 \mathrm{cms}$. variation each. The number of specimen in each group was categorized. Their average length and weight was noted ( Table 1) . The Log. of total length and body weight was calculated. It is denoted as $\mathrm{X}$ and $\mathrm{Y}$ respectively. The square and multiplication of $\mathrm{X}$ and $\mathrm{Y}$ was also calculated and then equilibrium constant (b) was find out by using formula given above. It is 3.2528.

The length weight relationship and growth coefficient was studied by many workers in many fishes in India and abroad like Hile 1936 in Lencicthys artsdi, Allen 1938 in Salman trutta Bell 1963 in Tunna, Antony Raja 1967 in Sardinella longicep, Chattergee 1980 in Labeo gonius, Hatikakoty and Bishwas 2004 in Oreochromis mosambicus Dahare 2011 in Barilius barila. In length weight relationship the growth coefficient ' $\mathrm{b}$ ' of the fish should be close to 3 It may ranges between 2.4 and 4.0 as 
reported by Hile 1936, Martin 1947, Dahare 2011. The value of the growth coefficient 'b' generally correlate the cube law 3 . When environmental conditions are optimum to the fish the value of $b$ is 3 or above 3 and when the value of $b$ is less than 3 indicate the environmental condition along with food stuff in

Table. 1-

\begin{tabular}{|c|c|c|c|c|c|c|}
\hline Sr. No. & Size group in cms. & $\begin{array}{c}\text { Number of } \\
\text { specimen }\end{array}$ & $\begin{array}{c}\text { Average total } \\
\text { length in cms. }\end{array}$ & $\begin{array}{c}\text { Average body } \\
\text { weight in gms. }\end{array}$ & $\begin{array}{c}\text { Log. of Total } \\
\text { length (X) }\end{array}$ & $\begin{array}{c}\text { Log of body } \\
\text { weight (Y) }\end{array}$ \\
\hline 1 & 2 & 3 & 4 & 5 & 6 & 7 \\
\hline 1 & $4.1-4.5$ & 12 & 4.246 & 0.201 & 0.6279 & -0.6968 \\
2 & $4.6-5.0$ & 14 & 4.748 & 0.263 & 0.6765 & -0.5800 \\
3 & $5.1-5.5$ & 10 & 5.292 & 0.396 & 0.7236 & -0.4023 \\
4 & $5.6-6.0$ & 23 & 5.768 & 0.473 & 0.7610 & -0.3251 \\
5 & $6.1-6.5$ & 32 & 6.291 & 0.674 & 0.7987 & -0.1713 \\
6 & $6.6-7.0$ & 12 & 6.824 & 0.879 & 0.8340 & -0.0589 \\
7 & $7.1-7.5$ & 15 & 7.312 & 1.103 & 0.8640 & 0.0425 \\
8 & $7.6-8.0$ & 8 & 7.824 & 1.482 & 0.8930 & 0.1708 \\
9 & $8.1-8.5$ & 3 & 8.372 & 1.850 & 0.9228 & 0.2671 \\
10 & $8.6-9.0$ & 4 & 8.700 & 1.980 & 0.9395 & 0.2966 \\
11 & $9,1-9.5$ & 3 & 9.301 & 2.253 & 0.9685 & 0.3527 \\
12 & $9.6-10.0$ & 2 & 9.800 & 2.850 & 0.9912 & 0.4548 \\
13 & $10.1-10.5$ & 4 & 10.350 & 3.563 & 1.0149 & 0.5518 \\
14 & $10.6-11.0$ & 3 & 10.733 & 3.833 & 1.0307 & 0.5835 \\
15 & $11.1-11.5$ & 2 & 11.300 & 4.600 & 1.0530 & 0.6627 \\
16 & $11.6-12.0$ & 1 & 12.000 & 5.800 & 1.0791 & 0.7634 \\
17 & $12.1-12.5$ & 2 & 12.300 & 5.850 & 1.0899 & 0.7671 \\
\hline $\mathrm{N}=17$ & & 150 & & & 15.2692 & 2.6789 \\
\hline
\end{tabular}

\section{Acknowledgement:}

The author thanks to Dr. A. G. Sontakke Ex. Director Institute of Science Nagpur for facilities and guidance.

\section{References:}

Allen K. R. (1938) Some observations on the biology of the trout (Salmo trutta) in wintermonths. J. Ani. Ecol. 7 : 333-349.

Antony Raja (1967) Length weight relationship in the oil sardine (Sardinella longicep). Indian J. Fish. $14: 159-170$.

Bell R. R. (1963) Length weight relationship for blue fin tuna in the California fishery. California Div. Fish and game.

Chatterji A. (1980) The relative condition factor and length weight relationship of the freshwater carp Labeo gonius (Ham) Ciprinidae teleost J. Bombay Natural Historical Society 77(3) : 435443. the water body is not sufficient for fish. In Wainganga river from Pauni of Bhandara district the environmental conditions for Mastacembelus pancalus are good hence the values of $\mathrm{b}$ are found to be more than 3 ie. 3.2528
Dahare Rajesh (1911) Length-Weight relationship of a riverine fish Barilius barila (Gunther) J. Aquac.Res. Dev. 2(3) : 114-115.

Hatikakoty and Bishwas (2004) Length weight relationship and condition factor of Oreochromis mossambicus (Peters) from a domestic pond Nazira upper Assam.Indian J. Env. And Ecoplan. 8 (1) :220 -236.

Hile R. (1936) Age and growth of the Cisco leucuichthys artedi (Le Sure) in the lake of three northern highland Wisconsin Bull. U. S. Bur. Fish 48 : 209-317

Le Cren E. D. (1951) The length weight relationship and seasonal cycle in gonadal weight and condition in perch (Perca fluviatilis) J. Animal Ecol. 20 : 201-219.

Martin W. R. (1949) The mechanics of the environmental controlof body form in fishes.Univ. TorontoStyd. Biol. 58 : 1 - 9 . 